\title{
NOTES
}

\section{CONTROL OF NONGOVERNMENTAL CORRUPTION BY CRIMINAL LEGISLATION}

\section{INTRODUCTION}

The problem of corruption of persons in a position of trust is an ancient one. ${ }^{1}$ Yet while there is a long history in the common law and legislation of attempts to control the corruption of those with governmental duties, ${ }^{2}$ attempts to control by criminal statute the corruption of persons whose duties are other than governmental is relatively recent. ${ }^{3}$ It is the purpose of this Note to explore the problem of nongovernmental corruption, to examine the statutes and decisions which have outlawed such corruption, and to discuss possible improvement of the statutory treatment.

The basic social problem which the statutes attempt to remedy can best be described by the adage, "every man has his price." A man who occupies a position in which others trust and rely upon his good faith usually feels some sense of duty toward the position and toward those trusting in him. However, such trust may be betrayed when that sense of duty is overcome by some greater motivational force. Not every betrayal of trust is corrupt. The overwhelming force may be some sense of a higher social or ethical duty-a sentry may desert his post to save a drowning child-in which event there is no corruption as the word is generally understood. ${ }^{4}$ However, positions of trust are often betrayed for some selfish reasonfrequently personal material gain-and such are the betrayals we label corrupt. It may be said, then, that corruption occurs when an individual is relied upon to conduct himself in accord with certain considerations relating to the interests of others and when that individual pretends to so

1 Clark \& Marshall, Crimes $\$ 14.02$ (6th ed. 1958).

2 Coke defined bribery as the offense committed "when any man in judicial place takes any fee or pension, robe, or livery, gift, reward or brocage of any person, that hath to do before him any way, for doing his office, or by colour of his office, but of the king only, unlesse it be of meat and drink, and that of small value ..." 3 COKE, INSTITUTES 145 (1648). Bribery was not long confined to judicial officers but soon embraced any person in public office. I Burdick, CrImes \$288 (1946).

3 The first English statute was the Prevention of Corruption Act, 1906, 6 Edw. 7, c. 34, which was amended by the Prevention of Corruption Act, 1916, 6 \& 7 Geo. 5, c. 64. Some American statutes are older. New York first passed such a statute in 1881 (see historical note following N.Y. PEN. LAws §439), and Massachusetts in 1904, Mass. Gen. Laws ANN. ch. 271, \$39 (1956). But see Coke's description of the ancient common-law crime of simony, an ecclesiastical offense which involved trafficking in spiritual favors in exchange for mundane goods. 3 CoKE, INSTITUTES 153 (1648).

4 Webster defines corruption as the "inducement (of a person) by means of improper considerations to commit a violation of duty." WEBSTER, NEW INTERNATIONAL Dictionary (2d ed. 1956). (Emphasis added.) 
conduct himself while in reality his considerations are directed incompatibly toward his own self-interest.

Attempts to prevent private corruption by means of criminal legislation have been notable especially in two fields. There are many state statutes which make it a crime to corrupt by bribery the agent or employee of another. ${ }^{5}$ Also widespread are statutes which make it criminal to influence by corruption the outcome of an athletic contest. ${ }^{6}$ Because the statutes treat differently commercial corruption and athletic corruption, and because the basic issues in the two areas are, to some extent at least, dissimilar, it appears desirable to consider separately these two groups of statutes.?

\section{CoRRuptron of EMPLOYEES}

Thirteen states have statutes which make it a crime to corrupt any agent or employee of another. 8 In addition to statutes of this "general" type, there are seventeen states which have statutes making it a crime to bribe a particular type of employee, ${ }^{9}$ notably agents or employees in charge of purchasing or hiring. ${ }^{10}$ Other common categories are telegraph and telephone personnel ${ }^{11}$ and common carrier personnel. ${ }^{12}$

In addition there are federal statutes which touch on this area-one makes it unlawful to bribe the employee of a railroad to influence his decision "with respect to the supply, distribution, or movement of cars." 13 Another covers labor representatives, ${ }^{14}$ and a third outlaws "commercial bribery" in the alcoholic beverage industry. ${ }^{15}$ Probably the most important federal legislation in the field is the section of the Federal Trade Commission Act which authorizes the FTC "to prevent . . . unfair methods of competition in commerce." 18 It has long been established that commercial bribery is such an unfair method of competition. However, the statute is

5 See chart following this Note, pp. 864-67 infra.

B Ibid.

7 There are, of course, many other areas of potential corruption in nongovernmental affairs-labor relations and communications have been in recent focus. While some considerations may well apply equally in all areas, each field presents individual problems and may be more meaningfully analyzed in isolation (though the end result might conceivably be the recommendation of similar statutory treatment for all). This Note, the purpose of which is to discuss what effect criminal legislation may have on private corruption, deals only with the two areas which have received significant positive legislative consideration.

8 See chart, pp. 864-67 infra.

9 Ibid.

10 Ibid.

11 Ibid.

12 Ibid. (1958).

13 Interstate Commerce Act §1, 54 Stat. 913 (1940), 49 U.S.C. §1(17) (b)

14 Labor Management Relations Act (Taft-Hartley Act) §302, 61 Stat. 157 (1947), 29 U.S.C. § 186(a) (1958).

(1952).

15 Federal Alcohol Administration Act, 49 Stat. 982 (1935), 27 U.S.C. §205(c)

16 Federal Trade Commission Act, 52 Stat. 111 (1938), as amended, 15 U.S.C. $\$ 45(a)(6)(1958)$. 
not a criminal one, and the FTC is limited in enforcing its policies to the use of cease and desist orders. ${ }^{17}$

\section{Commercial Bribery: the Problem}

The activity to which most of these statutes primarily direct their attention is what has commonly become known as "commercial bribery," a term of recent origin. ${ }^{18}$ A good working definition of the crime is embodied in a Seventh Circuit decision: "The vice of conduct labelled 'commercial bribery' . . . is the advantage which one competitor secures over his fellow competitors by his secret and corrupt dealings with employees or agents of prospective purchasers." ${ }^{19}$ There are three principal methods of accomplishing commercial corruption of this type: direct money bribery, indirect bribery through gifts and entertainment, and subsidies. ${ }^{20}$

\section{Direct Bribes}

A competitive supplier bribes the agent of a prospective customer to buy needed goods from him to the exclusion of rival sellers. The most obvious result of the bribe is that the purchaser no longer buys his goods in open competition. The resulting reduction of competition affects both the purchaser and the public. The purchaser is directly affected because he no longer has normal contact with the supplier's competitors and therefore cannot take full advantage of product and price differentials. The price paid for the goods received is increased not only by the amount of the bribe but often by an even greater amount since there is no longer any competitive pressure to hold the price down. In addition, there is the risk that the bribed agent may waste or destroy the goods with the purpose of creating an earlier need to reorder and thus initiating more frequent opportunities for the receipt of bribes. ${ }^{21}$ Experience has shown that once a foothold is gained in an industry, this type of bribery becomes rampant, ${ }^{22}$ since

17 Because the purpose of this Note is to explore the significance of criminal statutes in the control of corruption, the activity of the FTC will be alluded to only by footnote when relevant for purposes of comparison.

18 Clark \& Marshall, Crimes 915 (6th ed. 1958).

19 American Distilling Co. v. Wisconsin Liquor Co., 104 F.2d 582, 585 (7th Cir. 1939). The court derived this definition from the one employed by the FTC. "The following list illustrates unfair methods of competition . . 4. Bribing buyers or other employees of customers . . . without employers' knowledge . . . to obtain or hold patronage." 1957-58 FTC ANN. REP. 81. (Emphasis added.) The prescription that the transaction must be secret from the employer presents a significant contrast to a typical criminal statute dealing with similar conduct. See text following note 30 infra.

20 This classification and many of the ideas in the following discussion had their foundation in Stevens, Some Economic Consequences of Commercial Bribery, 7 HaRv. Bus. REv. 156 (1928).

21 See Baeder, Adamson Co., 4 F.T.C. 129 (1921).

22 Federal Trade Comm'n, Letter to Congress, S. Doc. No. 258, 66th Cong., 2d Sess. $4(1920)$. This letter urged Congress to pass legislation providing federal criminal sanctions for commercial bribery. The requested legislation has never been enacted, and no subsequent attempts to secure it have been discovered. Examination of the list of the proceedings of the FTC in the area of commercial bribery indicates 
the alternative open to nonbribers is loss of business. The effect upon the public is apparent. In order to absorb additional costs either price levels in the industry must rise, or the quality of goods must fall.

\section{Gifts and Entertainment}

Not all bribes need be straightforward, money-for-services transactions. ${ }^{23}$ There are more subtle ways in which the corrupter can reach his goal. The supplier can flatter, make gifts to and entertain the purchasing agent of his customer. The economic results of these more devious means are similar to those of direct forms of influence: again "normal" competition disappears and the additional expense of distribution must be added to suppliers' costs of doing business. However, the practice may well be more dangerous than the direct bribe for several reasons. There is a more complacent attitude on the part of both the public ${ }^{24}$ and the employer toward these practices-an employer who would not allow his purchasing agent to accept a money gift from a supplier is not so likely to be upset if a bottle of Scotch should pass at Christmas time. ${ }^{25}$ Also more people are likely to be susceptible to this subtler type of corruption. Because it does not appear so patently immoral, conscience is more easily dulled. ${ }^{26}$

\section{Salesman Subsidies}

A supplier subsidizes the salesmen of his retailing customer to push the supplier's brand of goods. ${ }^{27}$ Such subsidies may take the form of commissions, or they may be worked through contests in which the most successful salesman wins a prize. This type of commercial bribery differs from the other two in that no secrecy is involved; yet the same underlying purpose is served, and with substantially the same economic results. The kind of competition in prices, quality and service whose benefits inure to the retailer and are passed on to the consumer is largely replaced by competition among suppliers to be the most generous to salesmen. Again, of course, prices are raised by at least the amount of the subsidy.

the recurrent appearance of companies within a given industry during a brief time span. While this may be indicative of the enforcement procedures employed, it also discloses the pervasive nature of the conduct in these industries. See proceedings listed 16 C.F.R. $\$ 3.315$ (1949).

23 " [I]t is important to note that a reciprocity, . . . a value-for-value-relationship is rather the exception than the rule." Eliasberg, Corruption and Bribery, 42 J. CRIMr. L., C. \& P.S. 317,321 (1951).

24 See New Jersey Asbestos Co. v. FTC, 264 Fed. 509, 510-11 (2d Cir. 1920), which held that gifts and entertainment lavished on purchasing agents by suppliers did not affect the public and therefore could not be enjoined by the Federal Trade Commission. Such practice was thought to be "an incident of business from time immemorial" and no more destructive of the public interest than advertising.

25 Of course not all gifts or entertainment need be "corrupt." Much depends upon the friendship of the parties outside of business, the motive of the donor, the value of the gift, etc. But see the New York statute, note 30 infra, which, as a prophylactic measure, proscribes all gifts from a supplier to a purchasing or hiring agent.

26 Cf. Eliasberg, supra note 23, at 326.

27 See Kinney-Rome Co. v. FTC, 275 Fed. 665 (7th Cir. 1921) (gifts of premiums by a manufacturer to salesmen of retailers held not to constitute unfair competition). 


\section{Commercial Bribery: the Statutes}

The question is to what extent existing statutes are designed to control, and are effective to control, the types of situations just described. The New York statute ${ }^{28}$ outlaws the corruption of employees, agents and servants in general and of purchasing and hiring agents in particular. Since this statute is broadest in scope, has been more widely enforced than any other, and has served as a prototype for the legislation of several other states, ${ }^{29}$ it will be dealt with in some detail..$^{30}$

On its face, this statute appears well designed to control commercial bribery. The portion aimed specifically at purchasing agents is undoubtedly the most significant. A purchasing agent is flatly forbidden to receive "directly or indirectly" for his own or another's benefit, any "commission, discount, gift, gratuity or bonus" from a supplier. It should be noted that the employer's knowledge of the gift is no factor, nor is the purpose for which the gift is given. If "saying made it so," this clause alone would wipe out most commercial bribery: it proscribes the circuitous and frequently condoned forms as well as the direct cash bribe. However, suppliers' subsidies to customers' retail salesmen is not outlawed since the clause applies only to a retailer's purchasing, not to his selling, agents.

Another clause of the statute does outlaw some subsidies. It makes it unlawful for any person or any agent to use a document which is will-

28 N.Y. PEN. LAWS $\$ 439$.

29 Conn. Gen. Stat. Rev. \$53-266 (1958) ; Mass. Gen. Laws Ann. ch. 271, $\S 39$ (1956); Mrch. Comp. Laws \$ 750.125 (1948); Neb. Rev. Stat. \$ 20-710 (1956); N.C. Gen. Stat. \$14-353 (1953); S.C. Code \$16-570 (1952); VA. Code ANN. § 18-336 (1949); WIS. STAT. ANN. \$134.05 (1957), all are statutes substantially similar to New York's.

30 The text of the statute reads: "A person who gives, offers or promises to an agent, employee or servant of another, any gift or gratuity whatever, without the knowledge and consent of the principal, employer or master of such agent, employee or servant, with intent to influence such agent's, employee's or servant's action in relation to his principal's, employer's or master's business; or an agent, employee or servant who without the knowledge and consent of his principal, employer or master, requests or accepts a gift or gratuity or a promise to make a gift or to do an act beneficial to himself or to another, under an agreement or with an understanding that he shall act in any particular manner in relation to his principal's, employer's or master's business, or receives a reward for having so acted; or an agent, employee or servant, who, being authorized to procure materials, supplies or other merchandise either by purchase or contract for or on account or the credit of his principal, employer or master, or to employ service or labor for his principal, employer or master, receives directly or indirectly, for himself or for another, a commission, discount, gift, gratuity or bonus from the person who makes such sale or contract, or furnishes such materials, supplies or other merchandise, or from a person who renders such service or labor; and any person who gives or offers such an agent, employee or servant such commission, discount or bonus; and any person, corporation, partnership or other organization who shall use or give to an agent, employee or servant of another, or any agent, employee or servant who shall use, approve, or certify, with intent to deceive the principal, employer or master, any receipt, account, invoice or other document in respect of which the principal, employer or master is interested, which contains any statement which is wilfully false or erroneous in any material particular or which omits to state fully the fact of any commission, money, property or other valuable thing having been given or agreed to be given to such agent, employee or servant, is guilty of a misdemeanor and shall be punished by a fine of not more than five hundred dollars, or by imprisonment for not more than one year, or by both such fine and imprisonment." N.Y. PEN. LAw $\$ 439$. 
fully false so as to deceive an employer, or to fail to state on a document any commission or other valuable thing given to him as an agent. Thus, secret subsidies paid to retailers' salesmen are illegal. The real purpose of this portion of the statute, however, is to outlaw collusion and kickbacks between a buyer's agent and supplier even if the agent is not a purchasing agent-such activities cannot be hidden behind false weight slips and the like. In addition, the first, broadest clause of the statute encompasses the bribery of general agents and employees. But it is necessary that the bribe be undisclosed to the employer and be given for the purpose of affecting the employer's business.

\section{Commercial Bribery: the Cases}

The most salient feature of the cases in this area is that they are very few in number and most of those which are to be found are civil rather than criminal. Almost without exception the cases have arisen under the New York statute.

Only seven criminal cases involving the statute have been discovered. In 1915, a purchasing agent of R. H. Macy was indicted for accepting ten dollars in connection with a purchase of sponges. ${ }^{31}$ Defendant attacked the statute as unconstitutional on the grounds that the second clause: (1) singles out purchasing agents for special treatment, (2) curtails their freedom to contract, and (3) is not necessary to protect the welfare of the community. The court rejected all three assertions of unconstitutionality: (1) no violation of equal protection was found because the statute "affects alike all persons similarly situated"; (2) constitutional freedom of contract may be limited by police power; and (3) as to the propriety of the exercise of the police power in this situation, the court said:

"Without such a statute, under the fierce competition of modern life, purchasing agents . . . can be lured all too readily into service of hopelessly conflicting interests ... . Sound public policy, commercial honor, and the good faith of trusted . . . employes imperatively demand some such measure in the written law." 32

New York subsequently tried unsuccessfully to prosecute a bribed basketball referee ${ }^{33}$ and a union official. ${ }^{34}$ These convictions were upset because the individuals bribed did not fall within the class of persons at which the statute was directed. ${ }^{35}$ A professional photographer who had been con-

31 People v. Davis, 33 N.Y. Crim. 460, 160 N.Y. Supp. 769 (Ct. Spec. Sess. 1915). 32 Id. at 472,160 N.Y. Supp. at 777.

33 People v. Levy, 283 App. Div. 383, 128 N.Y.S.2d 275 (1954).

34 People v. Graf, 261 App. Div. 188, 24 N.Y.S.2d 683 (1941).

35 The basketball referee was held to be outside the reach of the commercial bribery statute because basketball is not a business or trade, the sphere of intended legislative concern. The court said that if the legislature had wanted to make a crime of bribing athletic officials it would have done so under the section of the code governing athletic bribery, N.Y. PEN. LAW $\$ 382$. The athletic bribery statute has since been amended to include officials. A similar holding was made with respect to the union officials. Unions were not business or trade. N.Y. PEN. LAw $\$ 380$ was regarded as the proper statute under which to charge a union official with corruption. 
victed for bribing a ship's purser to get a list of incoming passengers secured a reversal because the state had failed to show that the purser's employer was affected by the bribe. ${ }^{36}$ Other cases have involved the statute in its criminal aspect only indirectly. In United States $v$. Bruswitz, ${ }^{37}$ the defendant was convicted for failure to report commercial bribes as income in his federal tax reports, despite his contention that moneys received in violation of the bribery statute were accountable to his employer and hence not income. ${ }^{38}$ In situations concerning state licensing it has been decided that although the crime is only a misdemeanor, it does involve moral turpitude. Therefore, a lawyer convicted might be disbarred, ${ }^{30}$ and an insurance adjuster convicted might be refused a license by the Department of Insurance.40

Use of the New York statute in civil proceedings has been far more common. Sirkin v. Fourteenth St. Store, ${ }^{41}$ the leading case, involved a fact situation which is typical. The plaintiff sold and delivered a quantity of goods to the defendant and, upon failure of payment for the goods, brought an action for the price. Defendant sought dismissal on the grounds that the contract of sale was the result of a bribe which had passed between plaintiff and defendant's purchasing agent. Defendant buyer admitted that he suffered no injury because of the bribe but insisted that the court should refuse to enforce the contract of sale on "broad moral grounds." The court agreed, holding that if a buyer can show that the bribe and the contract of sale were parts of the same transaction, the sale will be considered void and the court will leave the parties as it finds them. Refusing judicial recognition to a contract which was procured by violation of a criminal statute was justified as helping to stamp out the practice of commercial bribery which the legislature had condemned.42 The rule of Sirkin, that a contract of sale entered into as the result of bribing an employee will not be enforced against the buyer, has become well established in New York. ${ }^{43}$ However, the court did enforce such a contract where

36 People v. Jacobs, 309 N.Y. 315, 130 N.E.2d 636, 139 N.Y.S.2d 28 (1955).

37219 F.2d 59 (2d Cir.), cert. denied, 349 U.S. 913 (1955).

38 Bruswitz, a solicitor of bids for the Bethlehem Steel Company, argued that the funds were not income because of his continued obligation to turn them over to his employer-urging an analogy to the rule then prevailing with regard to the tax treatment of embezzlement. The court held that such a continued obligation is of no moment because the tax is based on the beneficial enjoyment and control of the funds.

39 In re McNally, 252 App. Div. 550, 300 N.Y. Supp. 459 (1938).

401946 N.Y. Att'y Gen. Ann. Rep. 225.

41124 App. Div. 384, 108 N.Y. Supp. 830 (1908).

$42 \mathrm{~A}$ dissenting opinion, while in sympathy with the motives of the majority, argued that since the legislature had not provided civil sanctions in the criminal statute, the court should not read in such sanctions. Id. at 394, 108 N.Y. Supp. at 837.

43 Kraus v. H. Pacter \& Co., 134 Misc. 247, 234 N.Y. Supp. 687 (Sup. Ct. 1929) (action to replevy goods delivered); Bolotin v. Jefferson, 98 Misc. 603, 163 N.Y. Supp. 59 (Surr. Ct. 1917); General Tire Repair Co. v. Price, 115 N.Y. Supp. 171 (Sup. Ct. 1909) (action to recover for services rendered and supplies delivered). 
there was evidence that the buyer knew of the bribe offered before the sale and urged his agent to accept it. ${ }^{44}$ The contract has likewise been upheld when it appeared that the bribed employee had played no part, either directly or indirectly, in its negotiation. ${ }^{45}$ Also, where there was not " $a$ clear preponderance of evidence establishing the seller's criminality" ${ }^{46}$-as where the supplier thought he was paying a broker when in fact he was paying a purchasing agent ${ }^{47}$-the contract was held valid. The defense of bribery of one's agent cannot be utilized to ground an action for the return of purchase money already paid on the contract without a return of the goods, however: to recover the purchase money, there must be rescission. ${ }^{48}$

Another frequent situation finds the agent or employee suing the seller on their contract to recover the compensation promised for his services. Such a contract is of course not recognized if the seller can prove that it was in violation of the criminal statutes. ${ }^{49}$ However, the crucial issue may be whether the plaintiff was indeed an agent or employee of another or whether he was a bona fide independent broker. ${ }^{50}$ If the plaintiff is held an independent broker, the fact that he otherwise violated the statute by bribing an employee of a prospective client will not prevent the broker from collecting his commission from the person for whom he arranged a sale.51 Even if plaintiff is an employee, his employer's knowledge of his actions may save the employee's contract with the seller. ${ }^{52}$ But subsequent ratification by an employer who did not know of the bribe at the time it was arranged will not save the contract..$^{53}$

Several cases have dealt with the issue of who is entitled to the bribe money once paid, as against whom, and under what circumstances. In Fellmer v. Marino, ${ }^{54}$ plaintiff delivered money to defendant on the understanding that defendant would buy plaintiff a new car "at a price." When

44 Ballin v. Fourteenth St. Store, 123 App. Div. 582, 108 N.Y. Supp. 26 (1908), aff'd, 195 N.Y. 580, 89 N.E. 1095 (1909).

45 Merchants' Line v. Baltimore \& O.R.R., 222 N.Y. 344, 118 N.E. 788 (1918). Buyer's employee represented to seller that he could procure a contract for him. Employee accepted buyer's money but did nothing. Seller granted contract to buyer anyway.

40 Mutual Coal Co. v. H. G. Realty Co., 130 N.Y. Supp. 169 (Sup. Ct. 1911).

47 See Rosenwasser v. Amusement Enterprises, 88 Misc. 57, 63, 150 N.Y. Supp. 561, 564 (Sup. Ct. 1914).

48 Hearn v. Schuchman, 150 App. Div. 476, 135 N.Y. Supp. 52 (1912) (action for money had and received); Hearn v. Schuchman, 80 Misc. 311, 141 N.Y. Supp. 242 (Surr. Ct. 1913) (bill in equity brought on same facts as first Hearn case).

49 "[N]o court should be required to serve as paymaster of the wages of crime, or referee between thieves." Stone v. Freeman, 298 N.Y. 268, 271, 82 N.E.2d 571, 572 (1948).

50 See Clyde v. Schảller, 263 App. Div. 844, 31 N.Y.S.2d 686 (1941).

51 McConnell v. Commonwealth Pictures Corp., 1 Misc. 2d 751, 147 N.Y.S.2d

77 (Sup. Ct. 1955).

52 Le Bloas v. Zinn, 188 N.Y. Supp. 120 (Sup. Ct. 1921).

53 Babcock v. Warner Bros. Theatres, Inc., 240 App. Div. 466, 270 N.Y. Supp. 765 (1934).

544 Misc. $2 d$ 16, 158 N.Y.S.2d 24 (N.Y. City Munic. Ct. 1956). 
the car was not forthcoming, plaintiff sued to recover his money. Defendant claimed that since plaintiff knew that part of the money would go to bribe an automobile producer's agent to get the car, the contract was void. It was held that in the absence of a showing that plaintiff had known more than of the mere possibility of a bribe, defendant had failed to meet his burden of pleading and proving illegality as a defense. More common is the employer's attempt to recover the amount of the bribe either from his corrupt employee ${ }^{55}$ or from the corrupter. ${ }^{56}$ If the fact of bribery can be established-a jury question ${ }^{57}$ - the bribe money or fair value may be recovered from either party. It is no defense for the briber that he has already paid the bribed person; he must nevertheless pay over to the employer at least the amount of the bribe. ${ }^{58}$

\section{Commercial Bribery: the Sanctions}

The most obvious sanction is the punishment provided by the statutes -in New York a fine of up to $\$ 500$ and one year in jail. ${ }^{59}$ However, as the foregoing cases indicate, other sanctions are more frequently invoked and often more severe. If the guilty party's occupation is subject to state license, his right to engage in that occupation may be revoked. ${ }^{60} \mathrm{~A}$ corrupting supplier may lose the benefit of the contract procured ${ }^{61}$ or, if the contract is complete when the crime is discovered, he can be held liable to the injured party for damages ${ }^{62}$ or for the amount of the bribe. ${ }^{63}$ The employee, of course, is subject to immediate dismissal, ${ }^{04}$ has no claim for services rendered his employer, ${ }^{65}$ and must disgorge the amount of the bribe. ${ }^{68}$

55 Palmer v. Doull Miller Co., 233 Fed. 309 (S.D.N.Y. 1916) ; Sears, Roebuck \& Co. v. Kelley, 1 Misc. 2d 624, 149 N.Y.S.2d 133 (Sup. Ct. 1956).

56 Donemar, Inc. v. Molloy, 252 N.Y. 360, 169 N.E. 610 (1929).

57 Rosenberg v. Jefferson, 98 Misc. 616, 163 N.Y.S. 157 (Sup. Ct. 1917).

58 Donemar, Inc. V. Molloy, 252 N.Y. 360, 169 N.E. 610 (1929); see also In re Browning's Estate, 177 Misc. 328, 30 N.Y.S.2d 604 (Sup. Ct.), aff'd, 262 App. Div. 489, 30 N.Y.S.2d 606 (1941).

59 See chart, pp. 864-67 infra for statutory penalties in other jurisdictions.

60 See authorities cited notes 39,40 supra.

61 Sirkin v. Fourteenth St. Store, 124 App. Div. 384, 108 N.Y. Supp. 830 (1908).

62 Hearn v. Schuchman, 150 App. Div. 476, 135 N.Y. Supp. 52 (1912). The Rhode Island statute allows an injured plaintiff to recover double damages for injury caused by unlawful acts of the briber. R.I. GEN. LAwS ANN. \$11-7-6 (1956).

63 Donemar, Inc. v. Molloy, 252 N.Y. 360, 169 N.E. 610 (1929). The theory is that the amount of the bribe is added to seller's price and hence presumptively represents a minimum of damages to buyer. The doctrine is extremely useful, of course, in the typical case in which buyer cannot prove actual damages. 1956).

64 Sears, Roebuck \& Co. v. Kelley, 1 Misc. 2d 624, 149 N.Y.S.2d 133 (Sup. Ct.

65 Palmer v. Doull Miller Co., 233 Fed. 309 (S.D.N.Y. 1916).

66 Donemar, Inc. v. Molloy, 252 N.Y. 360, 169 N.E. 610 (1929). 


\section{Corruption in Athletic Contests}

The second area of nongovernmental corruption which has received significant legislative attention is the realm of athletics. ${ }^{67}$ Here the problems are seemingly moral rather than economic. The public as a whole does not suffer economically from athletic corruption (unless it be assumed that paying a price to witness a rigged contest is a complete waste) and there are but two private groups whose economic interests may be directly affected: those who make their living from staging or participating in athletic contests, and those who wager on the outcome of athletic contests. The economic interests of the former group will be at stake insofar as it is true that public interest in athletics wanes when corruption is discovered. Apparently the promoters themselves fear adverse economic effects from publicly disclosed corruption: both baseball and basketball have in the past subjected themselves to strenuous self-regulation when it was discovered that games had been fixed. ${ }^{68}$ But it is impossible to know whether or not it has been such cleanup campaigns that has kept those organizations from economic distress. As for the wagerers, it may be that an anti-fixing statute is justifiable as an instrument for their protection as a classparticularly for the protection of the small bettor under a lawful parimutuel or other legally condoned aleatory system-against the powerful professional combinations. But it is certainly debatable to regard the widespread athletic corruption legislation as representing solely a response to the financial interests of this particular and at best (except in the case of at-thetrack betting) legally marginal group.

Assuming that the general public suffers no such economic blow from athletic corruption as will suffice to explain its outlawing, why should legislatures be disturbed enough by such corruption to pass statutes against it? Is there any reason deeper than that people do not like to be fooled? It is often thought that an unrigged contest is more exciting than one with a predetermined outcome. Whether this is necessarily true is open to serious question. Certainly some of the most exciting television fare in recent years was the result of rigged quiz shows. On the other hand, few things are duller than a poorly rigged prize fight. Contest excitement might be said to depend not upon whether the contest is rigged, but rather upon how well it is rigged.

A second possible generating force is a psychological one. Most athletics are team sports. Each team usually has a loyal following who identify themselves with it. When a team member betrays his trust he disappoints and upsets that following. ${ }^{80}$ It may well be that the anti-

67 An annotated discussion of the problem may be found in Annot., 49 A.L.R.2d 1234 (1956).

68 The appointment of federal judge $\mathrm{K}$. M. Landis as Commissioner of Baseball following the Black Sox scandal of 1919 was the beginning of such self-policing policies.

$69 \mathrm{~A}$ letter to the editor of the Philadelphia Evening Bulletin maintained that Charles Van Doren's wrongdoing was not analogous to a fixed athletic contest because he had not "accepted money from gambling interests to lose, at the expense of those rooting for him." Philadelphia Evening Bulletin, Nov. 19, 1959, p. 26, col. 4. (Emphasis added.) 
corruption statutes in the area of athletics owe their existence, at least in part, to a desire to avoid such disappointments and to punish those responsible for them.

Perhaps another justification for making athletic rigging illegal is the influence such corruption has upon the participants who are corrupted. In the United States many athletic contests which generate public interest are interscholastic or intercollegiate. By definition the participants are often young and emotionally immature. In addition great emphasis is given-in the name of character building-to generating intense team loyalties. It is not unlikely that a corrupter who can convince a participant to betray his team loyalty for material gain will effect an attitudinal reaction with perhaps lasting effects upon the immature participant. ${ }^{70}$

\section{Athletic Corruption: the Statutes}

Thirty-two states have some sort of athletic corruption statute: ${ }^{71}$ thirty are of an exhaustive type which attempts to include all athletics and all participants, ${ }^{\mathbf{7 2}}$ one applies only to horse and dog racing and boxing, ${ }^{\mathbf{7 3}}$ and one to athletic contests for which an admission fee is charged. ${ }^{74}$ Once again the New York statute is the prototype for those of several other states. ${ }^{75}$ The statute covers in addition to certain specifically named sports "any professional or amateur game or sport" and forbids the bribing of "any player or referee or other official who participates or expects to participate." Arguably even broader is the Oregon legislation which includes "any athletic contest or game of any kind" and "any contest of ability or skill" 76 -provisions which would cover such activities as races "against the clock" which might not, under strict construction, be "games" or "sports." Other statutes are more extensive than New York's in regard to persons covered. ${ }^{77}$

The principal dimension in which all the statutes lack breadth is the type of corruption proscribed. With only one exception, the sole activity outlawed-in human contests-is bribery; Minnesota's statute ${ }^{78}$ alone also outlaws coercion as distinct from bribery. ${ }^{79}$ There is a general failure to

70 See Eliasberg, supra note 23 , at 323. "Lasting deviations from the path of honor may be the result of even the puniest bribe."

71 See chart, pp. 864-67 infra.

72 Ibid.

73 ArIz. Rev. Stat. ANn. \$§ 5-115, -205 (1956).

74 Ill. Rev. Stat. ch. 38, \$ 83 (a) (Smith-Hurd 1959).

75 ARk. Stat. AnN. \$41-903 (Supp. 1959); Conn. Gen. Stat. Rev. §53-287 (1958); Ky. Rev. Stat. § 436.506 (1959); Mass. Ann. Laws ch. 271, § 39A (1956); Mo. AnN. Stat. \$563.810 (Supp. 1958); W. VA. Code ANn. §6112(3) (1955), all are statutes substantially similar to N.Y. PEN. LAw $\$ 382$.

76 Ore. Rev. Stat. \$167.720 (1953).

77 ARK. STAt. ANN. $\$ 41-903$ (Supp. 1959), forbids bribing anyone "having any connection" with a "game or sport" to influence the outcome.

78 MinN. Stat. ANN. \$ 613.251 (1947).

$79 \mathrm{New}$ York has a separate, very broad statute which makes it a misdemeanor to coerce anyone into refraining from doing that which he has a legal right to do. N.Y. PEN. LAW §530. 
proscribe other, more subtle forms of rigging. For example, a typical horse race statute ${ }^{80}$ makes unlawful as a means of affecting race results not only bribery but also the use of drugs, mechanical devices and fraudulent practices. Thus it is criminal to artificially stimulate a horse, but it is no crime to give "pep pills" to a high school football player. The racing provisions probably should not be read as indicating more legislative regard for the health of thoroughbreds than for the health of young athletes. Rather the concern in this particular is undoubtedly protection of the bettor's interest, pari-mutuel racetrack betting as an institution being generally sanctioned while gambling on other contests is usually under at least some legal bans ${ }^{81}$ and hence, presumably, against public policy. Note that in the "pep pill" case, as in instances of bribery, the competition is being affected by factors other than the natural strength and skill of the participants; but the moral implications of such influencing may be regarded as different, since the athlete's performance is stimulated rather than depressed. ${ }^{82}$

\section{Athletic Corruption: the Cases}

Despite the number of statutes in this area, only a few appellate decisions involving athletic bribery have been discovered. The leading case is Glickfield v. State. ${ }^{83}$ There the defendant was convicted of offering the center on the University of Maryland football team $\$ 1,000$ to keep Maryland's margin of victory within twenty and one-half points in a given game. On appeal, defendant attacked the Maryland statute as unconstitutional for vagueness. The statute reads: "Any person or persons who shall bribe or attempt to bribe any persons participating in or connected in any way with any athletic contest held in this state shall be deemed guilty of bribery . . . ." 84 The court accepted a broad dictionary definition of bribe (to influence corruptly), held that money offered "to control the score" came within that definition, and found the language as applied sufficiently clear to withstand constitutional challenge. The court admitted that the common-law concept of bribery was limited to public officials but saw no bar to legislative enlargement to analogous situations. In a similar Iowa holding ${ }^{85}$-although here defendant was convicted of attempting to bribe a basketball player to ensure that his team lost by more than eight points-a sentence of ten years in county prison and a $\$ 10,000$ fine was upheld.

80 Ariz. Rev. Stat. Ann. § 5-115 (1956).

81 E.g., Cal. Pen. Code $\$ 337$ a(3); Fla. Stat. Ann. $\$ 849.14$ (1957); N.Y. PEN. LAW $\$ 986$ (bookmaking statutes).

82 The activity of artificially stimulating athletes requires multifaceted investigation before it can be adequately analyzed. Many factors necessary to analysisprevalence of the practice, effects on health, whether typically the athlete knows of the stimulant-could best be enlightened by legislative investigation.

83203 Md. 400, 101 A.2d 229 (1953).

$84 \mathrm{MD}$. ANw. CoDe art. 27, \$24 (1957).

85 State v. DiPaglia, 247 Iowa 79, 71 N.W.2d 601 (1955), cert. denied, 325 U.S. 1017 (1956). 
Two cases have involved rigged prize fights. In Casone v. State, the evidence indicated that defendant had promised cash to three fighters on one evening's card if they would "take a dive." Apparently defendant neglected to make good his promises and he found himself convicted of bribing one of the fighters on the testimony of the other two. The conviction was sustained against objections dealing principally with evidentiary matters of some significance in the administration of the law. ${ }^{87}$ People $v$. Philips ${ }^{88}$ involved the conviction of another prize fight rigger for offering $\$ 7,000$ to a fighter to lose. The fighter refused the bribe, but lost anyway. The state boxing commission investigated the fight, but the boxer himself told the commissioners that no bribe had been offered him. In court, however, he changed his tune and admitted that defendant had offered the money. The court held that the witness' change of face went only to credibility and that his testimony was sufficient to support the verdict.

\section{Athletic Corruption: the Sanctions}

Unlike the commercial bribery litigation, no athletic corruption cases seem to have arisen which presented the courts with opportunity to reinforce the statutes with civil sanctions. The criminal penalties themselves are in general more severe for this latter offense: ${ }^{80}$ the legislation usually calls for heavier jail sentences as well as heavier fines. ${ }^{90}$ Such as they are, the cases indicate that the courts have little hesitancy in applying maximum penalties. ${ }^{91}$ In addition, some statutes provide that the participant accepting or failing to report the bribe be barred from participation in the sport for life. ${ }^{92}$

\section{ConcLusion}

This survey of the present state of the law indicates at least two factors which inhibit the control of nongovernmental corruption by criminal legislation: (1) the statutes do not embrace the entire problem, and (2) the statutes insofar as they do go are not enforced to the fullest possible extent. Since the feasibility of wider legislation depends at least in part on enforceability, the latter problem is discussed first.

86193 Tenn. 303, 246 S.W.2d 22, cert. denied, 343 U.S. 969 (1951).

87 The court held that the two fighters were not accomplices to the crime of which the defendant was accused-fixing the third fight-and so could corroborate the testimony of the particular fighter whom defendant was accused of bribing. The fact that these witnesses testified to avoid prosecution for their own crime went only to credibility. It was no error for the state to present two veteran fight-goers to testify that the fights that evening looked fixed. Since the witnesses knew more about such things than an ordinary person and since they could communicate their knowledge to a jury, they qualified as experts.

8876 Cal. App. 2d 515, 173 P.2d 392 (Dist. Ct. App. 1946).

80 See chart, pp. 864-67 infra.

80 Ibid.

91 In State v. DiPaglia, 247 Iowa 79, 71 N.W.2d 601 (1955), defendant complained on appeal that a fine of $\$ 10,000$ and ten years in the state penitentiary was a cruel and unusual punishment for his crime. The court agreed that indeed there had been an error-the term of years should be served in county jail and not in the state penitentiary.

92 Ill. Stat. ANn. ch. 38, $\S 83($ b), (c) (Smith-Hurd Supp. 1959). 


\section{Enforcement}

In Massachusetts, where the prosecutor's discretion in regard to commercial bribery is removed by the terms of the statute, ${ }^{93}$ there have been no recorded criminal cases since its passage in 1904. In New York, where the statute is often invoked in civil proceedings, there are only a handful of criminal decisions despite strong indications in the civil litigation of indictable behavior. Since the statute in each of these states makes it unlawful for a supplier to give any gift to a purchasing agent regardless of motive or employer's knowledge, it is impossible to think that considerable violation of the statutes does not occur. The reason they are not enforced must lie elsewhere. A commentator on recently disclosed activities in the television industry has said:

"Pecuniary corruption in the political and commercial spheres must be expected . . . Public reaction to political and commercial corruption is as predictable as the incidence of corruption itself. The familiarity of the fact evokes complacency, especially since many an onlooker preserves his virtue only for lack of opportunity to sin. The public rises in indignation only when the magnitude of the outrage exceeds the customary, when corruptive practices run counter to the political and commercial mores-which are indifferent to some offenses, such as implicit bribery, but condemn others, such as open blackmail-or when a prominent member of the other party or of the competition has been caught." 94

This public complacency is probably the prime reason the statutes lack enforcement. Another reason is no doubt the difficulty of discovery and of procuring evidence concerning the kind of acts which fall within the statute. The activities necessary to accomplish these crimes require no violence, embody no traces in lasting form, and frequently have no witnesses other than individuals implicated or potentially implicated; once completed, they leave few persons, if any, aware of being damaged. ${ }^{95}$ These enforcement problems which arise from the very nature of the crimes are perhaps not altogether impossible to solve. The major step is to remove the selfincrimination privilege and grant immunity from prosecution to witnesses

93 "The district attorneys in their respective districts shall prosecute all violations of this law." Mass. ANN. LAws ch. 271, §39 (1956). (Emphasis added.)

84 Morganthau, Reaction to the Van Doren Reaction, N.Y. Times, Nov. 22, 1959, \$6 (Magazine), p. 17. In regard to the FTC, it is interesting that after a fierce flurry in the 1920's, the number of proceedings against commercial bribery dwindled rapidly. Today they are virtually extinct. (See proceedings listed 16 C.F.R. $\$ 3.315$ (1949).) The reason for the wane may be apathy, or it may be that since the early 1930's, and especially since the beginning of World War II, the FTC has been more than busy with other matters which it considers of greater importance. However it still lists commercial bribery as an unfair method of competition (see note 19 stipra) and it still writes commercial bribery into its Trade Practices Conference Rules. See, e.g., 16 C.F.R. §225.14 (1955).

95 It may be that the FTC, engaged in its constant industry-wide investigations, is better equipped to discover commercial bribery than is a district attorney who would be frequently less able to examine books and records. 
who participated in the crime. This has been done in several states. ${ }^{96}$ Such a provision, of course, need not necessarily lead to more prosecutions, but those which are instigated are more likely to be successful. A few states have gone even further to encourage discovery and in the case of athletic bribery provide that an athlete who fails to report a bribe attempt may be punished.97

In any event, difficulty of enforcement should not of itself preclude extension of the statutes into new fields. Recent events have shown clearly that wider coverage could be useful. Indeed, some observers believe that it is exactly in this type of field that criminal law best serves as a deterrent. ${ }^{98}$ Many crimes of corruption are of the so-called "white collar" variety-as are crimes involving restraint of trade, misrepresentation in advertising, financial fraud and violation of trust ${ }^{90}$ - and the mere fact that a criminal statute is on the books may be sufficient to dissuade some people from violating it whether or not it is frequently enforced. Moreover; no statute can be enforced unless it exists, and it may be expeditious to have an applicable provision in the statute books ready for use when public indignation is sufficiently aroused to promote enforcement.

\section{Wider Legislation}

The problem thus becomes one of how far to extend the concept of corruption and conflicting interest from the field of government into the sphere of economics and everyday life. Which violations of trust should be made criminal? Should it be a crime for a college professor to participate in the rigging of a television quiz show ? ${ }^{100}$ Should it be criminal for a disc jockey to be at the same time a producer of phonograph records? ${ }^{101}$

The definition of corruption set forth earlier in this Note ${ }^{102}$ suggests that corruption exists when an individual is relied upon to conduct himself in accord with certain considerations relating to the interests of others, and when that individual pretends to so conduct himself while in reality his considerations are directed incompatibly toward his own self-interest. Conceivably this definition could be embodied in a statute designed to

96 "Any person so compelled to testify in any such case shall be exempt from trial and punishment for the crime of which the person so testifying may have been a participant." Md. Ann. Code art. 27, § 24 (1957). See also Conn. Gen. Stat. Rev. § 53-268 (1958); La. Rev. Stat. \$14:73 (1950); Mass. AnN. Laws ch. 271, $\S 39$ (1956); N.Y. PEN. LAW \$ 439 (2).

97 Ill. Stat. ANN. ch. 38, $\$ 83($ b), (c) (Smith-Hurd Supp. 1959). Of course, the real solution lies in creating a moral climate in which it would be unacceptable to participate in this type of corruption and imperative to report bribe offers.

98 Cf. Sutherland, White Collar Crime 222 (1949).

99 Elitott, Crime in Modern Soctety 39 (1952).

100 See Note, Federal Communications Commission: Control of "Deceptive Pro. gramining", 108 U. PA. L. Rev. 868 (1960).

101 There may be a question as to whether commercial bribery, especially in its subtler forms, should be criminal at all. Perhaps it is better controlled by FTC-type regulatory proceedings than by criminal statute.

102 See text following note 4 supra. 
embrace all corrupt betrayals of trust. ${ }^{103}$ The purpose of such a statute should be not to replace, but rather to supplement existing legislation. The discussions of commercial and athletic bribery indicate that it is often important to have specific legislation aimed at particular areas of corruption. The legislature might well choose to treat purchasing agents differently from ordinary employees and corrupted athletes differently from their corrupters. However, in a dynamic economic society such as ours, new opportunities for corruption seem to appear constantly, and there exists a need for broad general statutes as well as narrow detailed ones. While new areas are being investigated, analyzed and passed upon by the legislature, it may be desirable to have a general catch-all statute which the prosecuting authorities could have available to enforce at their discretion. On the other hand, such general legislation presents the undeniable dangers of lack of clear warning in areas where the prevailing social mores may be ambiguous and of opportunities for discriminatory enforcement by complainants, prosecutors and criminal juries.

The issue of further anti-corruption legislation raises another question distinct from that of what activities should be proscribed-a question of who should do the proscribing. Should further statutes be on the state or federal level? Federal statutes at the present time are for the most part limited to very specific areas. ${ }^{104}$ However, the FTC long ago complained of the lack of criminal sanctions in the field of commercial bribery. ${ }^{105}$ More recently, the FCC has protested an inability to control a major part of the exposed corruption in the communications industry. Certainly many of the interests affected by nongovernmental corruption are peculiarly local, but the wide scope of the modern business, entertainment and communications communities makes many corrupt activities matters of national impact. The question of federal sanctions in this area involves not only the interrelationship of federal and state governments in terms of power and legitimate concern, but also problems of the propriety of imposing an additional burden on the Justice Department which might better devote its efforts to other federal interests.

R. D. R.

103 Such a statute might read:

Corrupt Betrayal of Trust

(1) It shall be unlawful for a person:

a) who is in a position such that he is relied upon by others faithfully to perform acts or to refrain from the performance of acts; and

b) who is aware of that position of trust; and

c) who pretends faithfully to perform his trust, to knowingly and willfully conduct himself or agree to conduct himself in contravention of the trust reposed in him.

(2) It shall be unlawful to knowingly induce or attempt to induce another to violate section (1) of this statute.

104 See notes 13-16 supra.

105 See note 22 supra. Section 1 of the Sherman Act, 50 Stat. 693 (1937), 15 U.S.C. $\$ 1$ (1958), which makes criminal every unreasonable combination in restraint of trade in interstate and foreign commerce could conceivably be used by the federal government as a weapon against commercial corruption. It appears never to have been so used. 


\section{COMMERCIAL BRIBERY}

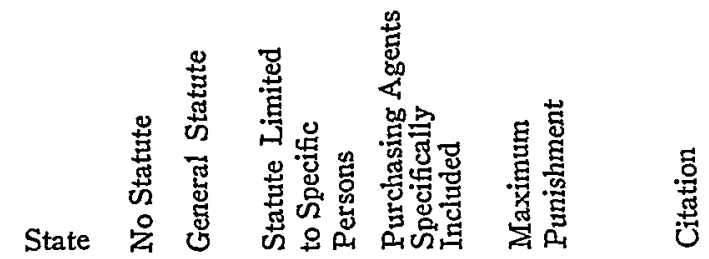

Ala. $\mathbf{x}$

Alaska $\mathbf{x}$

Ariz. $\quad a, b$

\$5M/5 yrs. ARIz. Rev. Stat. AnN. $\left\{\begin{array}{l}\$ 4-243 \\ \$ 13-291\end{array}\right\}(1956)$

Ark. $\quad \mathbf{x}$

Cal.

b

$\$ 5 M / 5$ yrs. CAL. Pen. Code $\S 641$

Colo. $\mathbf{x}$

Conn. $\quad x$

x $\quad$ x $\quad \$ 5 C / 1$ yr. Conn. Gen. Rev. Stat. $\left\{\begin{array}{l}\$ 53-266 \\ \$ 20-231\end{array}\right\}$

(1958)

Del. $\quad x$

Fla. $\quad x$

Ga. $\quad x$

Hawaii $\mathbf{x}$

Idaho $\mathrm{x}$

IIl. $\mathbf{x}$

Ind.

d $\$ 1 \mathrm{C}$

Ind. Ann. Stat. § 10-605 (1956)

Iowa $\mathbf{x}$

Kan. $\mathbf{x}$

Ky.

a

$\$ 5 \mathrm{C}$

Ky. Rev. Stat. $\$ 244.600$ (1959)

La. $x$

\$5C/1 yr. La. Rev. Stat. \$14:73 (1958)

Me.

e

\$3C/3 mos. ME. Rev. Stat. ANn. ch. 136, § 17 (1954)

Md. $\quad x$

Mass. $\quad x$

Mich. $\quad \mathbf{x}$

Minn. $\quad x$

Miss. $\mathbf{x}$

\section{Symbols:}

$\mathrm{U}=$ uncertain

$\mathrm{a}=$ alcoholic beverage personnel

$\mathrm{b}=$ telephone and/or telegraph personnel

x \$5C/1 yr. Mass. Ann. Laws ch. 271, § 39 (1956)

$c=$ embalmers

$\mathrm{d}=$ common carrier personnel

$\mathrm{e}=$ labor representative of public service corporation

$$
\begin{aligned}
& \mathrm{f}=\text { hiring personnel } \\
& \mathrm{g}=\text { labor representatives } \\
& \mathrm{h}=\text { bank officials } \\
& \mathrm{j}=\text { work gang foreman } \\
& \mathrm{k}=\text { mine foreman } \\
& \mathrm{l}=\text { chauffeur } \\
& \mathrm{m}=\text { stevedores }
\end{aligned}
$$


ATHLETIC CORRUPTION

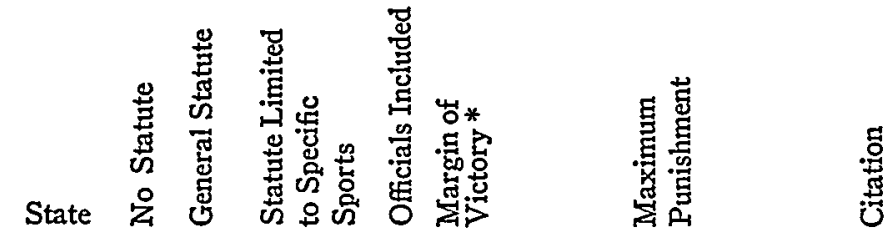

Ala. $\mathbf{x}$

Alaska $\mathbf{x}$

Ariz.

Horse

and Dog $x \quad \$ 5 M / 10$ yrs.

Ariz. Rev. Stat. Ann. \$\$ 5-115, -205 (1946)

Boxing

Ark.

Cal.

$\mathrm{x} \quad \mathrm{x} \$ 10 \mathrm{M} / 5 \mathrm{yrs}$.

ARK. Stat. § 41-903 (Supp. 1959)

$x \times \$ 5 M / 5$ yrs.

Cal. Pen. Code §337b

$x \quad x \quad \$ 10 M / 5$ yrs.

Colo. Rev. Stat. Ann. §40-12-2 (1953)

$\mathrm{U} \times \$ 10 / 10 \mathrm{yrs}$.

Conn. Gen. Stat. Rev. § 53-287 (1958)

$\mathrm{x} \$ 3 \mathrm{M} / 3$ yrs.

Dez. Code Ann. tit. 28, \$\$704, 709 (1953)

$\begin{array}{ll}\text { Del. } & \mathbf{x} \\ \text { Fla. } & \mathbf{x}\end{array}$

$\mathrm{x} \times \$ 10 \mathrm{M} / 10 \mathrm{yrs}$.

Fla. Stat. Ann. \$838.12 (Supp. 1958)

Ga. $\quad x$

Hawaii $\quad x$

Idaho $\mathbf{x}$

Ill.

U $x \$ 10 \mathrm{M} / 5 \mathrm{yrs}$.

HawaII REv. LAWS §265-7 (1955)

If pd.
admiss.

Ill. Stat. Ann. ch. 38, §83a (Smith-Hurd Supp. 1959)

Briber $=\$ 10 \mathrm{M} / 5 \mathrm{yrs}$

Ind. $\quad \mathbf{x}$

Iowa $\quad x$

$x \quad x \quad \begin{aligned} & \text { Bribed }=\$ 5 C / 3 \text { yrs. } \\ & \text { Amateur } \$ 1 M / 6 \text { mos. }\end{aligned}$

Ind. Ann. Stat. § 10-606 (1956)

$x \quad x \quad \$ 10 M / 10$ yrs.

Iowa Code ANn. § 739.12 (Supp. 1959)

Kan. $\mathbf{x}$

Ky. $\quad \mathbf{x}$

$\mathrm{U} \quad \mathrm{x}$ Briber $=\$ 10 \mathrm{M} / 10 \mathrm{yrs}$

Bribed $=\$ 10 \mathrm{M} / 5$ yrs. Ky. Rev. Stat. $\$ 436.505$ (1959)

La. $\mathbf{x}$

Me. $x$

Md. $\quad \mathbf{x}$

$\mathbf{x}$

U U $\$ 5 \mathrm{M} / 3 \mathrm{yrs}$.

MD. ANn. Code art. 27, $\$ 24$ (1957)

$\mathrm{U} \times \$ 1 \mathrm{M} / 2 \mathrm{yrs}$.

Mass. Ann. Laws ch. 271, §39A (1956)

$\mathrm{U} \times \quad \$ 2 \mathrm{M} / 4 \mathrm{yrs}$.

Micer. Stat. Ann. \$28.319 (Supp. 1957)

$\mathrm{x} \quad \mathrm{x} \quad \$ 5 \mathrm{M} / 5 \mathrm{yrs}$.

Minn. Stat. Ann. $\$ 613.251$ (Supp. 1959)

All but

prof. $U \times \$ 1 M / 5$ yrs.

Miss. Code ANn. §2034.5 (1956)

* It is often just as important to a rigger to predetermine the margin of victory as it is to predetermine the winner. 


\section{COMMERCIAL BRIBERY}

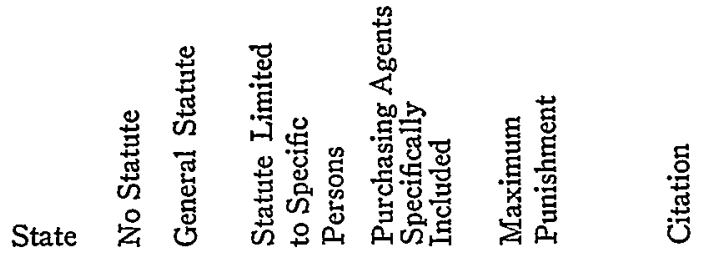

Mo. $\mathbf{x}$

Mont.

b

Neb. $\quad \mathbf{x}$

\$5M/5 yrs. Mont. Rev. Codes Ann. § 94-35-221 (1954)

Nev.

g, b

$x \quad \$ 5 C / 6$ mos. Neb. Rev. Stat. \$28-710 (1956)

N.H. $\mathbf{x}$

$\$ 1 M / 1$ yr. Nev. Rev. Stat. $\left\{\begin{array}{l}\$ 614.140 \\ \$ 707.120\end{array}\right\}$ (1956)

N.J. $\quad e, h, j, m$

$\$ 1 \mathrm{M} / 3$ yrs. $\quad$ N.J. Rev. StaT. $\left\{\begin{array}{l}\$ \$ 2 \mathrm{~A}: 91-1,93-8, \\ 93-9,32: 23-21\end{array}\right\}$ (1951)

N.M. $\quad x$

$\begin{array}{ll}\text { N.Y. } & \\ \text { N.C. } & \\ \text { N.D. } & \mathbf{x} \\ \text { Ohio } & \mathbf{x} \\ \text { Okla. } & \mathbf{x}\end{array}$

b

Pa. $\quad x$

R.I. $\quad x$

S.C. $\quad x$

S.D. $x$

Tenn. d

Tex.

Utah b

Vt. $\quad \mathbf{x}$

Va. $\quad x$

$\mathrm{x} \quad \$ 5 \mathrm{C} / 1$ yr. N.Y. PEN. LAw $\$ \$ 380,439$

$\mathrm{x}$ Discretion

N.C. Gen. Stat. § 14-353 (1953)

Wash. $\quad \mathrm{x} \quad \mathrm{g}, \mathrm{k}$

\$1M/1 yr. ORE. Rev. Stat. § 165.515 (1959)

$\$ 5 C / 1$ yr. Pa. Stat. Ann. tit. 18, \$ 4667 (1953)

$\$ 1 \mathrm{M} / 1$ yr. R.I. Gen. Laws ANN. \$11-7-3 (1956)

x $\$ 5 \mathrm{C} / 1$ yr. , S.C. Code $\$ 16-570$ (1952)

\$1C Tenn. Code Ann. \$39-821 (1955)

$\$ 1 \mathrm{M} / 1$ yr. Tex. Pen. Code art. 667-24 (1952)

$\$ 1 \mathrm{M} / 1$ yr. UTAH CODE ANN. § 76-48-12 (1953)

x \$5C/1 yr. VA. Code ANn. \$18-336 (1950)

$\$ 2 \mathrm{C} / 6$ mos. WASH. Rev. CoDE $\left\{\begin{array}{l}\S 49.44 .020 \\ \S 49.44 .060 \\ \S 78.34 .210\end{array}\right\}$ (1951)

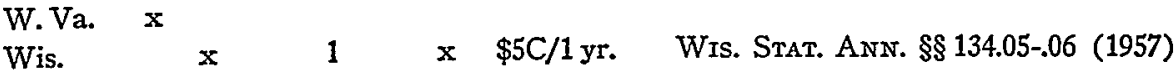

\begin{tabular}{lrrrr} 
Wyo. & $\mathbf{x}$ & & & \\
\hline Totals & 25 & 13 & 17 & 9
\end{tabular}

Symbols:

$\mathrm{U}=$ uncertain

$\mathrm{a}=$ alcoholic beverage personnel

$\mathrm{b}=$ telephone and/or telegraph personnel

$c=$ embalmers

$\mathrm{d}=$ common carrier personnel

$\mathrm{e}=$ labor representative of public service corporation

$f=$ hiring personnel

$\mathrm{g}=$ labor representatives

$\mathrm{h}=$ bank officials

$j=$ work gang foreman

$\mathrm{k}=$ mine foreman

$1=$ chauffeur

$\mathrm{m}=$ stevedores 
ATHLETIC CORRUPTION

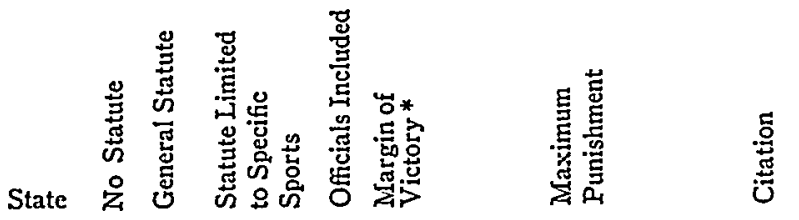

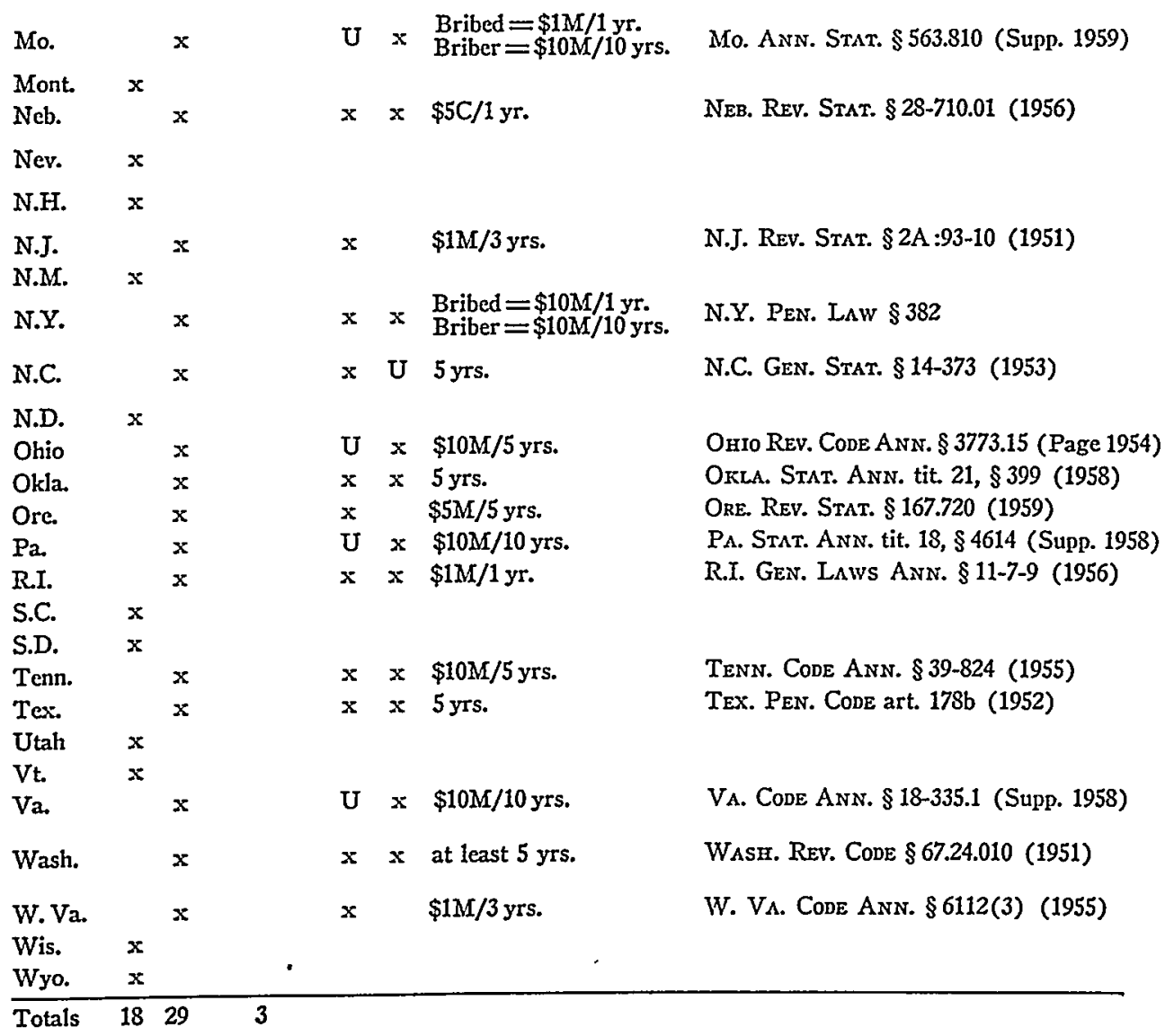

* It is often just as important to a rigger to predetermine the margin of victory as it is to predetermine the winner. 